\title{
Romanian Churches in Toronto: Not Yet Factors of Cohesion
}

\author{
LaUra Visan, York University
}

\begin{abstract}
Theorists of social capital have emphasized the catalyzing role that churches may play by strengthening community involvement and facilitating the development of personal networks. Churches that serve immigrant communities are viewed as pillars of stability, able to alleviate the cultural shock that many newcomers experience upon settling into their countries of adoption. However, this normative ideal is not always matched by reality. Building on thirty ethnographic interviews that I conducted with Romanian immigrants in Toronto, I aim to demonstrate that churches are not infallible in their cohesive efforts. They cannot compensate for the absence of interpersonal trust - a caveat inherited from the pre-1989 totalitarian era, and thus can hardly contribute to the consolidation of intra-community ties.

7 his article discusses the role of churches in social capital formation, with a focus on two of the most important

Romanian churches in Toronto: the Saint George Orthodox Church and the All Saints Orthodox Church. Building on thirty ethnographic interviews conducted in 2010 and 2011 with Romanian immigrants in Toronto and the Greater Toronto Area (GTA), I will show that my respondents' attitude towards the church is predominantly critical. The majority of them consider that the church does not yet function as a factor capable of strengthening interpersonal ties and mutual trust among Romanian immigrants. I begin with a discussion of my methodology and a literature review
\end{abstract}


on the catalyzing role that churches may play by strengthening community involvement and facilitating the development of personal networks. My article then shifts from a normative perspective to a more contextualised approach, anchored in the everyday experiences of the Romanian ethnic group. After briefly revisiting the pre-1989 context of the communist era, when the heads of the Orthodox Church often endorsed the Nicolae Ceausescu regime, I will turn to the responses collected from Romanian immigrants in Toronto. The experience of living in a social climate dominated by suspicion and the absence of interpersonal trust clearly reflects in my respondents' attitude towards churches. However, the critical discourse that most interviewees have towards the Romanian churches in Toronto should not be exclusively relegated to the inheritance of the communist era. I will present the expectations, hopes and unfulfilled expectations that my respondents shared regarding the activity of churches. I argue that the cohesive role of these institutions does not manifest irrespective of circumstances; instead, my study emphasizes the importance of contextualised analyses and the observation of the particularities of each ethnic community.

\section{Research Methodology}

I undertook thirty ethnographic open-ended interviews with Romanian immigrants in Toronto and the Greater Toronto Area who had immigrated to Canada after the 1989 anti-communist revolution in Romania. This methodology "requires listening carefully enough to hear the meanings, interpretations, and understandings that give shape to the worlds of the interviewees." To the highest extent possible, both genders were represented in balanced numbers. During Nicolae Ceausescu's political regime, the few individuals who were able to escape from the country in spite of the closed borders had a different motivation for leaving the country than the successive waves of Romanians who arrived in Canada beginning with the early 1990s. In the first stages of my research, the sample of respondents was gathered through my contacts among Romanian immigrants in Toronto and the GTA. Later, I applied a snowball technique, asking participants if they knew of any non-acquainted potential participants.

1 Herbert J. and Irene S. Rubin, Qualitative Interviewing - The Art of Hearing Data. (Thousand Oaks: Sage, 1995), 7. 
The Role of Church in the Formation of Social Capital Stocks: A Theoretical Review

The role that churches may play in fostering and developing social capital resources has been insufficiently researched. ${ }^{2}$ This may come as a surprising fact, considering the contribution of faith communities to the consolidation of civic culture in the United States. However, understanding the role of churches is important, because, as Robert Putnam maintains, these institutions "provide an important incubator for civic skills, civic norms, community interests and civic recruitment" 3 and an environment where churchgoers have the opportunity to practice skills such as public speaking and conflict management, while strengthening their capital of interpersonal trust. Putnam establishes a positive correlation between regular church attendance and various secular forms of community involvement, from school service attendance, to visiting friends and active membership in political clubs and farm organizations. ${ }^{4}$ Interest in civic participation may exist in the absence of regular churchgoing but voluntarily joining a congregation "necessarily involves accepting a set of norms - including the norm of contributing to the building of human and social capital and of being willing to participate in civic affairs." Many authors establish a positive correlation between regular churchgoing and secular forms of community involvement, including political participation. The positive role of churches in encouraging active community involvement also manifests in the sphere of political participation. Paul J. Weithman emphasizes the role of churches in constructing "realized citizenship," churchgoers' awareness of their

2 Corwin Smidt, ed., "Introduction," Religion and Social Capital. (Waco, Texas: Baylor University Press, 2003), 2.

3 Robert Putnam, Bowling Alone. The Collapse and Revival of American Community. (New York: Simon and Schuster, 2006), 66-67.

4 Ibid. See also Robert Wuthnow, Christianity and Civil Society: The Contemporary Debate. (Valley Forge, PA: Trinity International Press, 1996), 87 , for the positive influence of regular churchgoing on participation in community related activities and donating even for secular causes. 5 Ram A. Cnaan, Stephanie C. Boddie and Gaynor I. Yancey, "Religious Bowling Alone, But Serving Together; The Congregational Norm of Community Involvement," in Religion and Social Capital. ed. Corwin Smidt. (Waco, Texas: Baylor University Press), 2003, 20. 
rights and obligations, and willingness to assert them. ${ }^{6}$ Building on earlier scholarship, Weithman maintains that regular attendance at religious services usually translates into an increased interest in public matters, including voting. ${ }^{7}$ Pieter Bevelander and Ravi Pendakur also make this connection between regular religious attendance, and participation in elections; ${ }^{8}$ as does Jack Jedwab, who also contends that members of religious organizations are more likely to contact a politician or attend a demonstration. Thus, Canadians "who belong and participate in religious organizations are more likely to agree that people in government can be trusted (41\%) than those who have never belonged (31\%)."

The services that churches provide to disenfranchised citizens is particularly important in the context of neoliberalism, as is the role that churches may play in facilitating the settlement of immigrants in their host countries and preserving their ties with their homelands. Often, the role of a church in a community transcends the religious service. Ram A. Cnaan, Stephanie C. Boddie and Gaynor I. Yancey maintain that the activities of religious congregations in the United States "add to the quality of life in the community," from choirs and performances organized for the members of the congregation, to religious classes and help provided to homeless people. ${ }^{10}$ Churches in the United States outpace the workplace sector and the Rotary Club in providing the disenfranchised segments of the population with transferable civic skills. ${ }^{11}$ Charles Hirschman also emphasizes the significant role churches play in providing social and economic assistance for persons in need. ${ }^{12}$ In Canada, the advent of neoliberalism

6 Paul Weithman, Religion and the Obligations of Citizenship. (Cambridge: Cambridge University Press, 2002), 37.

7 Sidney Verba, Kay Lehman Schlozman and Henry E. Brady, Voice and Equality: Civic Voluntarism in American Politics. (Cambridge, MA: Harvard University Press, 1995), 322-324; Weithman, 41.

8 Pieter Bevelander and Ravi Pendakur, "Social Capital and Voting Participation of Immigrants and Minorities in Canada," Ethnic and Racial Studies. Vol. 32:8 (2009), 1407.

9 Jack Jedwab, "Religion and Social Capital in Canada," Diversity /

Diversité. Vol. 6.1. (2008), 33.

10 Cnaan, Boddie and Yancey, 21.

11 Ibid., 18-19.

12 Charles Hirschman, "The Role of Religion in the Origin and Adaptation of Immigrant Groups in the United States," International Migration Review. 
and the increasing metropolitan social polarization between a thin layer of high skilled and generously rewarded professionals and a widening segment of underprivileged citizens confined to modestly paying jobs has consolidated the position of churches as providers of social services. Susan D. Phillips identifies some forty-one programs and social activities available at congregations throughout Ontario, including counseling programs for children, elderly persons, underprivileged citizens, as well as programs centered on community empowerment and development." ${ }^{13}$

\section{Churches and immigrant communities}

According to the Canadian General Survey, a study conducted in 2003 on approximately 25000 respondents, immigrants attend religious services more often than native Canadians. Abdolmohammad Kazemipur considers that this is accountable to the difference in religious cultures that newcomers may have encountered in their homelands, and to Canadian secularism. ${ }^{14}$ However, John Biles and Humera Ibrahim observe that "very few research or policy initiatives examine the connection between religion and immigration in Canada" or the role of churches in the formation of social capital resources among newcomers and consider this a serious shortcoming in the multicultural model promoted by Canada. ${ }^{15}$ This topic should be granted more attention inasmuch as, upon arriving in a new country, numerous immigrants group themselves in socio-religious organizations that tend to "replicate as nearly as possible an old ethnic

Vol. 38/3 (2004): 1207.

13 Susan Phillips, "Voluntary Sector Government Relationships in Transition: Learning from International Experience for the Canadian Context," in The Non-profit Sectors in Interesting Times: Case Studies in a Changing Sector. eds. Kathy Brock and Keith Banting. Montreal and Kingston: McGill-Queen's University Press, 2002, 17-70; cited in Jedwab, 28.

14 Abdolmohammad Kazemipur, "Social Capital Profiles: Immigrants and the Native-born in Canada," Prairie Metropolis Centre Working Paper Series WP02-08. (2008), 13, (http://pcerii.metropolis.net)

15 John Biles and Humera Ibrahim, "Religion and Public Policy, Immigration, Citizenship, and Multiculturalism - Guess Who's Coming to Dinner?" in Religion and Ethnicity in Canada. eds. Paul Bramadat and D. Seljak. (Toronto: University of Toronto Press, 2005), 157. 
religious community in a new setting." ${ }^{16}$

Faced with the challenging experience of immigration, many newcomers cluster around the church, and tend to manifest an enhanced sense of self awareness. ${ }^{17}$ Seeking the inner strength to cope with the cultural shock of moving to a different country, immigrants seek the support of churches. In the process of identity searching and formation that lies at the core of the immigration experience, people need a factor of stability, and religious beliefs "provide an anchor as immigrants must adapt and change many other aspects of their lives and habits." ${ }^{18}$ These institutions represent "nucle(i) of conformity, stability and social order in communities that would otherwise be volatile,"19 as religion has the capacity to enhance the sense of belonging on both a personal and a group-level. ${ }^{20}$

In order to gain a better understanding of the mediating role that churches play between immigrants and their countries of origin, it is useful to examine the social and historical context of homelands, in this case, the relation that immigrants had with churches in their native countries. In the case of Romanian immigrants, the experience of living under the totalitarian regime of Nicolae Ceausescu should be carefully examined. As will be discussed below, several respondents explicitly correlated their reluctance about the activity of the Romanian churches in Toronto to the pre-1989 discourse of the Romanian Orthodox Church which, in their view, did not take a firm stance against Nicolae Ceausescu's abuses. Understanding the past represents thus a necessary step when looking at the relation that Romanian immigrants have developed with their churches in Toronto.

\section{The Romanian Orthodox Church before and after 1989}

In what follows, I will briefly revisit the social and political climate

\section{Ibid.}

17 Steven Vertovec, Religion in Migration, Diasporas and Transnationalism. Vancouver Centre of Excellence. Research on Immigration and Integration in the Metropolis. Working Paper Series. No. 02-07, 2002, 11.

18 Hirschman, 1212.

19 Cnaan, Boddie and Yancey, 20.

20 Vincentia Joseph, "The Religious and Spiritual Aspects of Clinical Practice. A Neglected Dimension of Social Work," Social Thought. Vol. 13.1. (1987), 17; cited in Cnaan, Boddie, and Yancey, 25. 


\section{Romanian Churches in Toronto:}

of pre-1989 Romania, in order to clarify why churches could not exert their role of civic skills incubators. ${ }^{21}$ Nicolae Ceausescu was the Secretary General of the Romanian Communist Party and the president of Romania from 1965 until he was overthrown following the December Revolution in 1989. Juan J. Linz and Alfred Stepan aptly characterize the Ceausescu regime as sultanistic, in that the president regarded Romania as his personal property. ${ }^{22}$ The social climate of the era was dominated by a widespread feeling of suspicion, taking into consideration that even one's family members or close acquaintances could act as informers to the Securitate, the feared secret police, in exchange for material benefits or for a job promotion. As Eric Uslaner notes, "if people are wary of strangers they will limit their social activities to close friends whom they do see as trustworthy." ${ }^{23}$

The Nicolae Ceausescu regime had a dual attitude towards religious institutions; the president had "occasional dialogues" with the heads of the Romanian Orthodox Church but also continued to promote an atheistic, anti-religious discourse. ${ }^{24} \mathrm{An}$ irreversible consequence of this anti-religious campaign was the demolition of several churches to which many Bucharesters were profoundly attached; one of these churches was the Vacaresti Monastery, built in 1716, the largest $18^{\text {th }}$ century monastery in the South-East of Europe. It was demolished in 1984, in order to make room for a Palace of Justice that was never constructed. The Patriarch Teoctist, the head of the Romanian Orthodox Church between 1986 and 2009, was a controversial figure, due to his ties with Ceausescu's communist regime. He did not take a stand against the demolition of centuries-old churches, nor did he protest against the massacre in Timisoara on December $19^{\text {th }} 1989$, when dozens of people who protested against Nicolae Ceausescu were killed by the military. Instead, the Patriarch sent a telegram to

21 Putnam, 66-67.

22 Juan José Linz and Alfred C. Stepan, Problems of Democratic Transition and Consolidation: Southern Europe, South America, and Post-Communist Europe. (Baltimore, MD: The Johns Hopkins University Press, 1996), 347. 23 Eric Uslaner, "Trust and Civic Engagement in East and West," in Social Capital and the Transition to Democracy. eds. Gabriel Badescu and Eric Uslaner. (London: Routledge, 2003), 81.

24 Trond Gilberg, "Religion and Nationalism in Romania," in Nationalism in Soviet and East European Politics. ed. Sabrina P. Ramet. (Durham, NC: Duke University Press, 2003), 183. 
Nicolae Ceausescu, in order to congratulate him for his reelection as the leader of the Romanian Communist Party at the November 1989 congress. ${ }^{25}$

However, not only the church hierarchs engaged in acts of collaboration with the communist authorities; priests also "used to make incredibly overt allusions to the regime of terror we were living under in the last period. I eventually found out that they worked for the Securitate and were simply putting the people to a test," a Bucharester remembers. ${ }^{26}$ Several persons in my ethnographic sample also criticized the Romanian Orthodox Church for its position towards the communist regime: "the Romanian church is subservient to the political power, whatever power this is. During communism, they never made an official protest statement against the regime. There were several priests who protested, but they were soon excommunicated, and the Mitropoly endorsed the regime." (A.V.). "It was more comfortable for them [the heads of the Church] to keep quiet and to reap the benefits..." (M.C.).

After 1989, the Romanian Orthodox Church continued to occupy a prominent position in public life, offering "support and legitimization to any government as long as blessings and privileges continued to come from the state."27 Cristian Romocea considers that the demand of the Romanian Orthodox Church to be recognized as a national church was problematic, the same as its unwillingness to admit its collaboration with the Nicolae Ceausescu regime.

To the critics in the civic society add numerous media articles exposing cases of corruption among the hierarchs of the Romanian Orthodox Church or "the shameless and ambiguous tariffs, most often not fiscalized and not visibly displayed, which are required by some priests for serving in the religious celebrations." 28 The media also

25 Lavinia Stan and Lucian Turcescu refer to Teoctist as "the Unrepentant Penitent" in Religion and Politics in Post-Communist Romania. (Oxford: Oxford University Press, 2007), 66.

26 Martor. 2003. Revista de antropologie a Muzeului Taranului Roman

(The Museum of the Romanian Peasant Anthropology Review). Vol. 7, 2002.

(http://memoria.ro/index.php).

27 Cristian Romocea, "Church-State Relations in Post-1989 Romania," Journal of Church and State. Vol. 53 (2), (2011): 246.

28 Marius Vasileanu, "De ce scade increderea in Biserica?" ("Why is the General Trust in Church Decreasing?”) Hotnews.ro, 2011. (http://www. hotnews.ro/). 


\section{Romanian Churches in Toronto:}

Not Yet Factors of Cohesion

voiced the disapproval of numerous Romanians towards the intended construction of a giant People's Cathedral in Bucharest in a time of prolonged economic crisis. Notwithstanding the critics mentioned, the Romanian Orthodox Church has a positive public perception. According to a 2003 poll issued by the Gallup Institute Romania for the Soros Foundation, the church ranks first among the most reliable institutions; thus, $88 \%$ of the interviewees have much or very much trust in the church. ${ }^{29}$ The level of trust decreased from $88 \%$ in 2003 to $73 \%$ in 2011 but the latter percentage still places the Church on the first position in a ranking of most reliable public institutions in Romanians' trust. ${ }^{30}$ It may be hypothesized that Romanians, while aware of the questionable facets in the activity of this institution, are willing to regard it in a rather tolerant fashion, given that the Church represents the space where faith may be exercised. Or, as a wellknown Romanian saying that goes "do what the priest says, not what the priest does." However, this positive attitude towards the Church has not led to a consolidation of interpersonal trust; according to Eric Uslaner and Gabriel Badescu, Romania has a lower stock of trust than all other East European transition states. ${ }^{31}$

\section{Romanian churches in Toronto, from a normative ideal to everyday reality}

The following is an analysis of the answers provided by the thirty Romanian-Canadians from Toronto, on their attitudes towards the Romanian Churches they visit. The theoretical perspectives reviewed in the first part of my article present churches as spaces of cohesion, able to strengthen the social capital resources of a particular community; however, my respondents had different experiences to share, complaining about the incapacity of churches to strengthen the

29 The Gallup Organization, "Barometrul de opinie publica". Fundatia pentru o societate deschisa - Romania, 2003. ("The Public Opinion Barometer." The Foundation for an Open Society, Romania) http://www. gallup.ro/.

30 Vasileanu (http://www.hotnews.ro/).

31 Eric Uslaner and Gabriel Badescu, "Honesty, Trust, and Legal Norms in the Transition to Democracy: Why Bo Rothstein Is Better Able to Explain Sweden than Romania," in Creating Social Trust in Post-Socialist Transition. eds. Janos Kornai, Susan Rose-Ackerman, and Bo Rothstein. (New York: Palgrave, 2004), 32-39. 
intra-community ties at the level of the Romanian ethnic group. Five out of thirty respondents still regard the church through a positive lens, as a space where they can pray and, as in the words of one, "feel connected with God". To these persons, the church has an affective significance, as it evokes the years spent in Romania. Nevertheless, more than three quarters of respondents criticized the activity of Romanian churches in Toronto; their reasons for dissatisfaction will be discussed in detail below.

Only five out of thirty respondents would have expected the Romanian Orthodox Church to adopt an overtly critical attitude against Nicolae Ceausescu's communist regime, and are yet unable to 'reconcile' with the Church for this reason. Interestingly though, even if the connection between the heads of the Church and the communist authorities was explicitly mentioned by a small number of interviewees, the absence of cohesion, stemming from the generalized suspicion that characterized interpersonal relations during the totalitarian decades, is visible in most responses I collected. More than three quarters of interviewees mentioned the incapacity of the church to act as a catalyst for Romanian immigrants.

Four out of thirty respondents referred exclusively to the moral support that the Romanian churches provided them in the difficult process of settlement. V.C. arrived in Canada in 1996; at that time, the Saint George Orthodox Church was the only place where she could meet other Romanians, and this was where she created her group of friends and her network of acquaintances. C.M. mentioned the emotional comfort she found at the church, which made her integration in Canada less difficult. "It was good to meet other Romanians there, to listen to their stories and understand that they had a difficult start, too. It helped me a lot." C.M. is the only respondent who, in gratitude for the moral support she found in the church, would be willing to do volunteer work if, in the future, she could identify an activity related to arts. For G.P.:

(The church) creates stability... when you have a church, you no longer feel lost... it is like home, the priest is wearing the same clothes as home... you see babushkas wearing headscarves, same as home. At the church you baptize your children. Our daughter was born and baptized here, and we are godparents for other children... other people got wed here. 


\section{Romanian Churches in Toronto:}

\section{Not Yet Factors of Cohesion}

Some years ago, you could hear people "I am going to have my wedding in Romania," now it is no longer the case. Even if they have the wedding in Mexico, the religious ceremony is at the Romanian church. There is also a Romanian cemetery, the priest from All Saints has bought a piece of land in Stouffville. When you bury your dear ones somewhere close, there is your land... you no longer need to go home."

I also asked the Romanian-Canadians about the role that a church serving an immigrant community should play. I sought to ascertain whether the Romanian churches in Toronto fulfill my respondents' expectations. C.B. believes that a church should act as a factor of cohesion for the members of an ethnic community and to help them establish bonds based on mutual trust. He considers, however, the Italian and Polish churches to be closer to this ideal image than the Romanian churches in Toronto. To R.T., the church should represent "the light from home" and should organize more events aimed to strengthen the ties between churchgoers. Living in a predominantly Portuguese neighborhood, he often witnessed the events organized by Portuguese churches, and would like to see the Romanian churches following this model. C.L. views the church as a "catalyst that should bring people together and promote cultural values."

However, twenty-five out of thirty interviewees have more pragmatic expectations from the Romanian churches, emphasizing the socializing role of these institutions and the networking opportunities that may be pursued here. A respondent remembered her surprise when somebody recommended her to go to the church in order to develop her real estate business. "I wouldn't have thought of something like this, as far as I knew you'd go to the church for a different purpose, but it looked like a common practice. Yes, the church is more of a community centre..." (O.M). The respondents suggested that the Romanian Church should be more active in assisting newcomers with information about employment and accommodation, and that it should help them improve their language skills and expand their network of connections. This echoes Charles Hirschman's idea that churches represent "one of the most important sources of support for the practical problems faced by immigrants." 32

32 Hirschman, 1212. 
S.M. considers that the Romanian churches should provide some kind of support for overcoming the homesickness that a newcomer experiences, and more important, some practical advice on day-today matters:

An immigrant gets through more phases, and I think the beginning is the most painful. The immigrant heads towards the church to search for help. The church should try to provide more counseling to the immigrant, because at some point you feel that the society is hostile to you, doesn't help you... you need somebody to talk to, not necessarily the priest but somebody from the church. Then, some counseling about the labour market would be helpful, on how to search for jobs... and some counseling about the Canadian society, what is an OSAP, how to deal with real estate, how to buy insurance. The state gives you welfare, it's $\mathrm{OK}$, but you need more than that.

F.V. also considers that the Church should providehands-on counseling to immigrants: "anybody coming from the other end of the world has thousands of questions. You are seeking somebody who went through the same experience, and if you don't have friends, the church is the first place to go." C.T. suggests that a "buddy system" implemented by the Romanian churches, with older immigrants assisting newcomers, would facilitate the settlement process. She considers that some informative pamphlets containing basic information for newcomers should be available at the church. Another respondent agrees that the church should do more in supporting newcomers, but considers that donors are more accountable for this phenomenon rather than the church, which is just a channel for the funds obtained from donations. Building on their personal experiences, the respondents stated that the church should play a more active role in facilitating the settlement of newcomers.

None of my interviewees received any kind of material support from the Romanian churches in Toronto and the Greater Toronto Area, or heard of such cases. M.T., for instance, remembered that upon arriving in Canada, his father felt the need to get in contact with the Romanian community, but his endeavour was not successful. "Interestingly, he got help from the Jewish community, which gave him some stuff for the house." M.H. and her former husband did 


\section{Romanian Churches in Toronto:}

Not Yet Factors of Cohesion

not receive any support from the Romanian Church, but from the Hungarian one. "I am half Hungarian. When we arrived in Canada, the Hungarian Church gave us some furniture and found us a place to live. It was a great help, all in all. We had known a Hungarian lady and she put us in touch with the church." C.B. has neither received help from the church, nor has he heard of such case. Instead, he mentioned a Baptist Church in Kitchener: "it is a very strong community, they help each other a lot, even help each other to come to Canada. They hold tight together, not like the Orthodox." V.C. did not even expect any kind of material support from the Church. "I knew they could not provide it". However, even if the interviewee only received spiritual solace from the Church, she used any opportunity to offer her support to other churchgoers or to the institution itself: "we had a blind lady who needed surgery. Her son was abroad in Europe, studying, and she needed help. Together with two other ladies, I helped her: she needed somebody to stay with her after surgery. Then we took her back home from the hospital and we cooked for her."

Out of the thirty persons in my research sample, only V.C. and S.P. contribute their time to the church. At the same time, they conscientiously attend the religious service of the George Orthodox Church and the All Saints Church, respectively. V.C. is actively involved in the Sfantu Gheorghe Romanian church in Toronto, from organizing various parties for Romanians, Christmas or Easter celebrations, to cleaning the premises whenever necessary.

I volunteer a lot, both at the church and together with my friends... At the church (St. George Orthodox Church, my note) I do many things, from cleaning the washrooms to organizing New Years' Eve and other parties, the Autumn Ball, the Spring Ball... when my daughters were younger and lived with me, we tried to organize disco evenings for young people. It was surprising to have something like that in a church, some were suspicious, how can you have a disco at the church, but we had some very successful attempts.

S.P. is a member of the parochial council of the All Saints Church in Toronto. He is actively involved in organizing the Romanian school and the Romanian cultural centre that function at this church. Together with his wife and other two persons, the respondent teaches 
lessons to the children who attend the Romanian school each Sunday, and help them organize small shows for Easter and Christmas. He also undertakes various administrative activities, from bureaucratic tasks to selling candles for the religious service.

At the church I am involved in administration, and the Romanian school and the Romanian cultural centre. I am a member of the parochial council, and I teach at the Romanian Sunday school. My wife, I and two other persons, four enthusiasts, make presentations to the children...every Sunday we take turns. Twice a year, on Easter and Christmas, we organize a small show. The administration work is very demanding as well, because we are very few people taking care of everything, from paperwork to selling candles.

It is worth mentioning, however, that even these two respondents who are devout churchgoers consider that some aspects in the activities of the Romanian churches need improvement. V.C. mentions that "we could do more to provide some help for the people in need, and I would like the church to make more efforts toward educating the young generation in the spirit of religion, understood not as a barrier but as a landmark for life." S.P. considers that the church "should unite Romanians, it should be a factor of trust"; instead, he noticed that the churchgoers are divided in 'two gangs", depending on the church they frequent: "they accuse each other of being communists and Securitate agents. Many of them are still anchored in the past era; particularly those who came to Canada before the 1989 Revolution are very suspicious". S.P. also refers to an "administrative fear" associated to the risk of becoming subordinated to the Romanian patriarchy. Priests may be relocated to other places, thus losing the privilege of serving in much coveted locations, such as Canada or the United States. The respondent believes that such tensions among churchgoers accurately reflect the fragmentation and lack of cohesiveness that character the Romanian community of immigrants in Toronto and the GTA. In this sense, he remembers that the church he attends, All Saints, was unable to realize its wish to co-operate with St. George church to organize the yearly celebration of Romanians in Toronto. "We offered to help them with ideas, to contribute with funds, but they kept us aside."

Even the interviewees who attend the church sporadically have 


\section{Romanian Churches in Toronto:}

their own reasons for dissatisfaction. It may be argued that their perspectives lack substance, considering the infrequency of their visits to the Romanian churches. However, these persons used to attend the church on a more regular basis, but some aspects in the activity of churches discouraged them from doing so. At the same time, their opinions provide useful insights on the activity of these institutions and, most important, emphasize the potential for positive change in the services provided by churches. S.M. wishes that the Romanian churches were more active in attracting volunteers. She remembers how difficult it was for her teenage son to be accepted as a volunteer in the renovation of the St. George Orthodox Church in Toronto. C.L. might accept to contribute his time to the Romanian churches if these institutions could gain his trust. "I never felt close enough to the community that I perceive as representing the church here," he admits. N.D. finds that the priest is sometimes too persistent: "he [the priest] should not say 'forget about golf, come to the church.' I am not a golf player but nevertheless, the priest shouldn't say that... he should let the people come to the church when they feel the need, if they want to do so, not bring them in with the harpoon." However, N.A. noticed some improvement in this concern: "in the past, the priests' focus was to bring people to the church, and for this they gave you a lot of negativist reasons, in which all the sentences began with 'thou shall not,' and what happened if you didn't come... Now, they seem to be more understanding, to look at the positive side of things to make people come to the church."

C.L. considers that, instead of strengthening the bonding ties among Romanian immigrants, churches are far too interested in advertising their activities through various diasporic media outlets. According to C.B. and E.P., churches should grant more attention to younger generations: "every time I went, $90 \%$ of the people were 50 and over." Three respondents are dissatisfied with what they call a "money-oriented" attitude of the church. R.T., who has a limited trust in the Romanian churches from Toronto, is disappointed by the fact that the material interests of the church often come to prevail, while the activities meant to bring Romanian immigrants together are relegated to a secondary plan. This is the main reason that prevents him from contributing time to the church. Similarly, D.V. is uncomfortable with the intensive fundraising efforts of the Romanian churches: "they were making too much propaganda on this, they were 
pushing forward their need for money... you were facing a wall when going to the church: the money." C.T. recalls her attempt to organize a fundraising event to the benefit of a person from Romania who needed an expensive surgery. The Romanian Church refused to assist her in any way; furthermore, it refused to reduce the $\$ 500$ rental fee for the ballroom in the basement, where the respondent would have wanted to organize the event.

\section{Conclusion}

My research has examined the cohesive potential of Romanian churches in Toronto and the Greater Toronto Area, building upon thirty ethnographic interviews with Romanian immigrants residing in this area. I have contrasted my respondents' encounters with the church with the theories discussed in the first section of my article. Theorists have insisted upon the catalyzing mission of churches that serve ethnic communities; however, for more than three quarters of my respondents, this mission fails to materialize. This is mainly due to a feeling of suspicion inherited from the communist era, which divides churchgoers, depending on the church they frequent. The interviewees would also like the Romanian churches to be more actively engaged in assisting newcomers or in attracting young people towards the church. Five out of thirty respondents recalled that the heads of the Romanian Orthodox Church failed to take a firm stand against the abuses of the Nicolae Ceausescu regime, or even endorsed them.

Although the responses I collected were predominantly critical towards the activity of Romanian churches, several respondents were grateful to these institutions for the moral support provided. "You no longer feel lost when you have a church", a respondent mentioned, remembering his difficult years as a newcomer in Canada. Other interviewees emphasized that churches should play a catalyst role, by strengthening bonding ties among Romanian immigrants and promoting Romanian cultural values.

The interviews I conducted revealed other differences between the catalyzing role that, in theory, churches play and the day-to-day reality of newcomers. As Pieter Bevelander and Ravi Pendakur, and Jack Jedwab contend, churchgoing usually correlates with volunteering, philanthropy and the higher vote presence in elections; however, this 
does not apply to the Romanian-Canadians I interviewed. ${ }^{33}$ Charles Hirschman emphasizes the significant role churches play in providing social and economic assistance for persons in need. ${ }^{34}$ As mentioned above, my respondents considered that the Romanian churches in Toronto should provide more consistent support for newcomers or for other categories of people who may need it.

Through contextualized research, I sought to understand how immigrants' living practices negotiate the normative ideals of the scholarly literature. The responses I received from the Romanian Canadians included in my research sample demonstrate that churches should not be deemed infallible in their catalyzing mission; in the case of Romanian immigrants from Toronto, churches cannot compensate for the absence of interpersonal trust. It is important to mention, however, that I only interviewed first generation immigrants; it remains to be seen whether second generation Romanian immigrants, who did not have the experience of living in the suspicion-dominated climate of the Ceausescu era, will develop a more trustful relationship with the churches, and if these institutions will be more capable of strengthening the bonding ties among churchgoers.

33 Bevelander and Pendakur, 1407; Jedwab, 33.

34 Hirschman, 1207. 


\section{Bibliography}

Bevelander, Pieter and Ravi Pendakur. "Social Capital and Voting Participation of Immigrants and Minorities in Canada," Ethnic and Racial Studies. Vol. 32:8 (2009): 1406-1430. http://dx.doi.org/10.1080/01419870802298447

Biles, John and Humera Ibrahim. "Religion and Public Policy: Immigration, Citizenship, and Multiculturalism - Guess Who's Coming to Dinner?" in Religion and Ethnicity in Canada. eds. Paul Bramadat and D. Seljak. Toronto: University of Toronto Press, 2005, 154-177.

Cnaan, Ram A., Stephanie C. Boddie and Gaynor .I. Yancey. "Religious Bowling Alone But Serving Together; The Congregational Norm of Community Involvement," in Religion and Social Capital. ed. Corwin Smidt. Waco, Texas: Baylor University Press, 2003, 19-31.

Gilberg, Trond. "Religion and Nationalism in Romania," in Nationalism in Soviet and East European Politics. ed. Sabrina P. Ramet. Durham, N,C.: Duke University Press, 2003, 170186.

Hirschman, Charles. "The Role of Religion in the Origin and Adaptation of Immigrant Groups in the United States," International Migration Review. Vol. 38/3 (2004): 12061233. http://dx.doi.org/10.1111/j.1747-7379.2004.tb00233.x

Jedwab, Jack. "Religion and Social Capital in Canada," Diversity / Diversité. Vol. 6.1. (2008): 25-46.

Joseph, M.Vincentia. "The Religious and Spiritual Aspects of Clinical Practice. A Neglected Dimension of Social Work," Social Thought. Vol. 13.1. (1987): 12-23. http://dx.doi.org/10.1080/15426432.1987.10383583

Kazemipur, Abdolmohammad. "Social Capital Profiles: Immigrants and the Native-born in Canada," Prairie Metropolis Centre Working Paper Series, WP02-08. (2008). (http://pcerii. metropolis.net). 
Romanian Churches in Toronto:

Not Yet Factors of Cohesion

Linz, Juan José and Alfred C. Stepan. Problems of Democratic

Transition and Consolidation: Southern Europe, South America, and Post-Communist Europe. Baltimore, MD: The Johns Hopkins University Press, 1996.

Martor (2003). Revista de antropologie a Muzeului Taranului Roman.

(The Museum of the Romanian Peasant Anthropology Review). Vol. 7, 2002. (http://martor.memoria.ro/index).

Phillips, Susan D. "Voluntary Sector - Government Relationships in Transition: Learning from International Experience for the Canadian Context," in The Non-profit Sectors in Interesting Times: Case Studies in a Changing Sector. eds. Kathy Brock and Keith Banting. Montreal and Kingston: McGill - Queen's University Press, 2002, 17-70.

Putnam, Robert D. Bowling Alone: The Collapse and Revival of American Community. New York: Simon and Schuster, 2006.

Romocea, Cristian. "Church-State Relations in Post-1989 Romania," Journal of Church and State. Vol. 53 (2), 2011, 243-277. http://dx.doi.org/10.1093/jcs/csq136

Rubin, Herbert J. Rubin and Irene S. Rubin. Qualitative Interviewing - The Art of Hearing Data. Thousand Oaks: Sage, 1995.

Shmidt, Corwin, ed. "Introduction," Religion and Social Capital. Waco, Texas: Baylor University Press, 2003, 1-18.

Stan, Lavinia and Lucian Turcescu. Religion and Politics in PostCommunist Romania. Oxford: Oxford University Press, 2007. http://dx.doi.org/10.1093/acprof:oso/9780195308532.001.0001

The Gallup Organization. Fundatia pentru o societate deschisa Romania; Barometrul de opinie publica - Romania, 2003. ("The Public Opinion Barometer." The Foundation for an Open Society, Romania) (http://www.gallup.ro/). 
Uslaner, Eric M. "Trust and Civic Engagement in East and West," in Social Capital and the Transition to Democracy. eds. Gabriel Badescu and Eric Uslaner. London: Routledge, 2003, 8194. http://dx.doi.org/10.4324/9780203428092

Uslaner, Eric M. and Gabriel Badescu. "Honesty, Trust, and Legal Norms in the Transition to Democracy: Why Bo Rothstein Is Better Able to Explain Sweden than Romania," in Creating Social Trust in Post-Socialist Transition. eds. Janos Kornai, Susan Rose-Ackerman, and Bo Rothstein. New York: Palgrave, 2004, 31-53. http://dx.doi.org/10.1057/9781403980663

Vasileanu, Marius. "De Ce Scade Increderea in Biserica?" (Why is the General Trust in Church Decreasing?) Hotnews.ro. 2011. (http://www.hotnews.ro/).

Verba, Sidney, Kay Lehman Schlozman, and Henry E. Brady. Voice and Equality: Civic Voluntarism in American Politics. Cambridge, MA: Harvard University Press, 1995.

Vertovec, Steven. Religion in Migration, Diasporas and Transnationalism. Vancouver Centre of Excellence. Research on Immigration and Integration in the Metropolis. Working Paper Series. No. 02-07, 2002.

Weithman, Paul. Religion and the Obligations of Citizenship. Cambridge: Cambridge University Press, 2002. http://dx.doi.org/10.1017/cbo9780511487453

Wuthnow, Robert. Christianity and Civil Society: The Contemporary Debate. Valley Forge, PA: Trinity International Press, 1996. 